\title{
Do Countries with Greater Credit Constraints Receive More Foreign Aid?
}

\author{
$\underline{\text { Subhayu Bandyopadhyay, Sajal Lahiri, and Javed Younas }}$
}

\begin{abstract}
Donor nations may recognize that some developing nations face credit constraints in the world capital market. This knowledge may prompt donors to increase aid flows to alleviate the constraint. In such a situation, flows of foreign aid and foreign loans to developing nations may be substitutes for each other. The authors use data from 114 aid-recipient countries over the 1997-2008 period to investigate the relationship between foreign aid and foreign loans. The central finding is that this relationship is negative, lending support to the substitution hypothesis. (JEL F35, O16)
\end{abstract}

Federal Reserve Bank of St. Louis Review, November/December 2012, 94(6), pp. 481-93.

onvinced that foreign aid does not work, Bauer (1971) argued that it should be replaced by free or easier access to the international credit market. He argued that foreign aid is

misused by recipient countries and the need to repay loans would compel the recipients to use them more effectively. $\underline{-}$ Even when foreign aid is effective, it is not clear a priori that it is the best form of assistance from abroad. On the other hand, the development of financial markets, as measured primarily by better access to credit, is known to foster growth and reduce poverty (e.g., Beck, Demirgüç-King, and Levine, 2007; Beck, Levine, and Loayza, 2000; Levine, 2003).

Foreign aid and foreign loans may be related through several channels. One possible channel is that developing nations may want to invest in infrastructure so they can be more productive in the future. Given their limited ability to raise resources from within their own countries, these nations may have to rely on foreign sources, which can take the form of aid inflows or loans. Depending on the creditworthiness of these nations, perhaps established by their history, such loans may or may not be available from the international capital market. If they are not available, or available at extremely high interest rates, the ability of nations to invest in public inputs may be limited. In such situations, there is an incentive for altruistic donor nations to step in and provide aid to alleviate this resource crunch for developing nations. If this is the

Subhayu Bandyopadhyay is a research officer and economist at the Federal Reserve Bank of St. Louis. Sajal Lahiri is a professor of economics and Vandeveer Chair at Southern Illinois University-Carbondale. Javed Younas is an assistant professor of economics at the American University of Sharjah, Sharjah, United Arab Emirates. The authors thank Asmaa Shahid Mahmood and E. Katarina Vermann for their excellent research assistance.

(c) 2012, The Federal Reserve Bank of St. Louis. The views expressed in this article are those of the author(s) and do not necessarily reflect the views of the Federal Reserve System, the Board of Governors, or the regional Federal Reserve Banks. Articles may be reprinted, reproduced, published, distributed, displayed, and transmitted in their entirety if copyright notice, author name(s), and full citation are included. Abstracts, synopses, and other derivative works may be made only with prior written permission of the Federal Reserve Bank of St. Louis. 


\section{Bandyopadhyay, Lahiri, Younas}

case, then donor nations will have a larger incentive to provide foreign aid to nations that have more difficulty borrowing from the world capital market.

Extensive evidence suggests that private firms in many developing countries face severe credit constraints. Galindo and Schiantarelli (2003) provide supporting evidence of constraints for several Latin American countries. Harrison and McMillan (2003) find that many manufacturing firms in the Ivory Coast face severe credit constraints. Using firm-level data in the manufacturing sector for six African countries, Bigsten et al. (2003) estimate the extent of credit constraints among firms of various sizes. Héricourt and Poncet (2007) find binding credit constraints among private manufacturing firms in China. Finally, Rajan and Zingales (1998) provide extensive evidence of sector-level financial development (or the lack of it) for 41 developed and developing countries.

The discussion above implies that donor nations may try to compensate for the lack of access to capital markets for some developing nations. This type of compensation may show up in the data as increased availability of aid for the most credit-constrained nations. This is the focus of our empirical investigation in the remainder of the article.

Using a dynamic panel-data framework that draws on 114 developing countries for 1997 through 2008, we examine whether the flow of more loans reduces the flow of foreign aid. Data on foreign aid are collected from the Organisation for Economic Co-operation and Development (OECD); we use offshore bank loan data from the Bank for International Settlements (BIS) locational banking statistics to measure access to foreign borrowing. Our empirical procedure uses an advanced estimation technique on the data and attempts to address a host of estimation issues; ignoring these would risk estimation bias and inconsistency. Our findings confirm that better access to international loans by developing countries reduces the amount of foreign aid they receive.

The next section describes the data and variables used in our study. We then outline the empirical model and methodology. Our estimation results and conclusions follow.

\section{THE DATA AND VARIABLES}

Our empirical analysis of 114 aid-recipient countries over the 1997-2008 period offers a separate analysis on the allocation of total and bilateral foreign assistance, the data for which are from the online database of the Development Assistance Committee (DAC-2011) of the OECD., 2,3 The aid data contain net disbursements for development objectives and thus exclude military aid. We convert these data into constant year-2005 U.S. dollars [USD] using the consumer price index for low- and middle-income countries and then dividing by the recipient country's population to express the dependent variable as aid per capita to account for a recipient's size effect.

We use offshore bank loan data from the BIS locational banking statistics to measure access to foreign borrowing. ${ }^{4}$ These data contain cross-border loans to all sectors in developing countries from banks located in the BIS reporting countries. Since these are cross-border loans, local lending by banks in a BIS member country is not included. For example, loans to India are those from BIS reporting banks located outside India. India is a BIS reporting country, but local lending in foreign currencies by banks located in India is not included in the cross-border borrowing. The cross-border lending data are based on the location of the reporting institutions and, there- 
fore, measure the activities of all banking offices located in each reporting country. Such offices report exclusively on their own unconsolidated business, which thus includes international transactions with any of their own affiliates. $\underline{\underline{5}}$

BIS adjusts the quarterly loan data for exchange rate changes. It also converts the relevant flow of new loans (net of repayments) in each quarter of the year into its original currency using end-of-period exchange rates and subsequently converts the changes in stocks into dollar amounts using period-average exchange rates. We convert the quarterly observations into annual observations by summing data for the four quarters. As for foreign aid, the figures for loans are also corrected for the size effect of the recipient country by expressing loans in per capita terms. $\underline{6}$

While drawing control variables, we take guidance from the empirical literature on aid. Gross domestic product (GDP) per capita (in constant year-2000 USD) captures the altruistic motivation for aid allocation. An obvious drawback of using GDP per capita as a proxy for economic need results from its skewed distribution because of high income inequalities in developing countries. Thus, as an alternative measure of economic needs, we also use infant mortality rates in some of our model's specifications. ${ }^{-}$Population is included to examine the size-related biases in aid allocation as past studies consistently find that countries with smaller populations receive more aid. 8 Trade openness (the percentage of exports plus imports to GDP) captures the influence of trade and macroeconomic policies of a developing country on aid allocation. This approach also resonates well with the commercial motives of donor nations in giving more aid to economically open regimes (e.g., Younas, 2008). While inflation measures macroeconomic instability, its squared term is included to examine its diminishing effect on aid. Data for all these control variables are from the online resource World Development Indicators (2010) of the World Bank.

A prodigious empirical literature on aid finds that democratic countries receive more aid (e.g., Alesina and Dollar, 2000, and Trumbull and Wall, 1994). Thus, we use data on "political rights and civil liberties" from Freedom House (2010). "Political rights" refers to freedom of a country's people to participate in the political process through voting, organizing their own political party, and forming effective opposition. "Civil liberties" entail the freedoms of expression and religious belief and the rights to protest and form unions. Each of these two indexes is measured on a scale from 1 (best) to 7 (worst). Following Trumbull and Wall (1994) and Younas and Bandyopadhyay (2009), among others, we first add and then revert these two indexes so the resulting index ranges from 2 (worst) to 14 (best). As a robustness check, we also use data on "voice and accountability" compiled by Kaufmann, Kraay, and Mastruzzi (2009). Their index uses scores between -2.5 and 2.5, where a higher value indicates that citizens are able to participate in selecting their government and enjoy freedom of expression, freedom of association, and free media.

We use a log-log model to estimate foreign aid allocation for the following reasons: (i) Most variables in our study (e.g., aid per capita, loans per capita, GDP per capita, population size, and trade openness) vary across a wide range and exhibit a skewed distribution. Therefore, log transformation smooths the data. (ii) This smoothing reduces the effect of outliers on estimates.

(iii) The estimated coefficients can be interpreted as elasticities. Table 1 lists the descriptive statistics. $\underline{9}$

In addition to the above control variables, all of our econometric specifications include time-invariant, country-specific fixed effects to account for the usual politico-strategic consid- 


\section{Table 1}

\section{Descriptive Statistics}

\begin{tabular}{lccccc} 
Variables & $\begin{array}{c}\text { No. of } \\
\text { observations }\end{array}$ & Mean & SD & Minimum & Maximum \\
\hline Ln (Real net total aid per capita) & 1,347 & 5.234 & 0.316 & 0.000 & 6.530 \\
Ln (Real net bilateral aid per capita) & 1,347 & 5.241 & 0.247 & 0.000 & 6.368 \\
Ln (Net offshore bank loans per capita) & 1,368 & 9.279 & 0.260 & 0.000 & 10.288 \\
Ln (GDP per capita constant year-2000 USD) & 1,359 & 6.940 & 1.206 & 4.390 & 9.739 \\
Ln (Infant mortality rate) & 1,368 & 3.651 & 0.795 & 1.065 & 5.056 \\
Ln (Population) & 1,368 & 15.828 & 1.873 & 11.172 & 21.004 \\
Ln (Trade/GDP, \%) & 1,334 & 4.312 & 0.487 & 2.763 & 5.647 \\
Ln (Inflation) & 1,358 & 3.502 & 0.363 & 0.000 & 6.365 \\
Ln (Political rights and civil liberties) & 1,368 & 1.975 & 0.486 & 0.788 & 2.639 \\
Ln (Voice and accountability) & 1,368 & 0.961 & 0.302 & 0.000 & 1.502
\end{tabular}

NOTE: SD, standard deviation. Data for all variables range from 1997 to 2008. Total aid is the sum of bilateral and multilateral aid. Loan data from BIS are adjusted (by BIS) for exchange rate movements.

erations for aid allocation. We also include time dummy variables in all specifications to account for unexpected events (e.g., flood, drought, or other calamities) that may lead to aid spikes for any given year (Younas and Bandyopadhyay, 2009).

\section{THE MODEL AND METHODOLOGY}

Consider a world that consists of a developed donor nation, a developing nation that is the recipient of foreign aid, and a third country-say "rest of the world" (ROW). The donor and the recipient nations are small in both the output market and the international credit market in the sense that goods prices and the borrowing rate (for the developed nation) are determined in the ROW and taken as given by the other two nations. The major difference between the donor and recipient nations is that the donor can borrow any amount at a given interest rate from the ROW, while the recipient cannot borrow beyond a certain level. The borrowing limit on the developing nation creates a wedge between the international interest rate and the rate faced by the recipient. This is one way to think of credit constraints for developing nations. Now, if the credit limit for the developing nation is relaxed, it reduces the endogenous interest rate in the developing nation. This raises the income level for the borrowing nation. Assuming a diminishing marginal utility of income, the altruistic donor nation endogenizes this rise in income for the recipient and reduces its aid dollars (at the margin). Thus, there is a negative relationship between access to the international loan market and the flow of foreign aid. The following empirical analysis builds on this idea.

To analyze the effects of foreign loans on foreign aid, we estimate the following dynamic panel-data model: 


$$
\ln (\text { aid, p.c. })_{i t}=\alpha_{0}+\alpha_{1} \ln (\text { loans, p.c. })_{i t}+\alpha_{2} \ln (\text { aid, p.c. })_{i, t-1}+X_{i t}^{\prime} \lambda+\kappa_{t}+\eta_{i}+\varepsilon_{i t},
$$

where $i$ refers to countries, $t$ to time, $\kappa_{t}$ to year-specific effects, $\eta_{i}$ to country-specific fixed effects, and $\varepsilon_{i t}$ to the usual disturbance terms. $X$ is the vector of control variables as discussed previously. The lagged dependent variable is included to capture persistence in aid allocation over time. As mentioned earlier, both aid and loans are expressed in per capita terms.

The following econometric concerns guide our choice of the empirical methodology: (i) the joint effect of endogenous variables in aid regressions such as foreign loans, GDP per capita, and trade openness, among others; (ii) unobserved country-specific factors that may correlate with other explanatory variables; and (iii) the persistence in aid allocation over time. Theoretically, it is plausible that the flow of aid may also influence the financial market-and thus the availability of credit. In fact, similar arguments for the possible simultaneous causation can also be advanced for the existence of poverty, trade openness, and democracy in an aid-recipient country. A conventional solution to deal with this issue is to use the method of two-stage least squares. Since we use the fixed-effects model specifications, any chosen instruments should exhibit variation over time. Moreover, the validity of instruments demands their high correlation with the instrumented variables but no correlation with the dependent variable. Thus, the difficulty of finding such instruments and their data for developing countries renders this approach infeasible.

In view of the above limitation, we resort to the generalized method of moments (GMM) estimation technique. In a panel framework, two types of GMM estimators can be used: the difference-GMM as proposed by Arellano and Bond (1991) and the system-GMM as proposed by Blundell and Bond (1998). As for the issue of endogeneity, the former takes the first difference of the data and then uses lagged values of the endogenous variables as instruments. Arellano and Bover (1995), however, point out that the lagged levels as used in the difference-GMM are often poor instruments for the first differences. The system-GMM estimator, on the other hand, improves efficiency by mitigating the weak instruments problem in the difference-GMM by using additional moment conditions. $\frac{10}{}$ It combines regression equations in differences and in levels into one system and uses both lagged differences and lagged levels as instruments for the endogenous variables. This estimator is also particularly well suited for a large cross section (our 114 nations) and a small number of time periods, as in our application. Moreover, it has also been favored in several recent studies for deriving estimations in a dynamic panel framework (e.g., Asiedu and Lien, 2011, and Loayza et al., 2012).

However, some researchers point out that the system-GMM estimator uses too many instruments and thus may suffer from the problem of "instruments proliferation." Hayakawa (2007) argues that the system-GMM estimator is less biased than the difference-GMM estimator even though the former uses relatively more instruments. In view of this concern, we run two specification tests for each regression: (i) the Hansen $J$-test of overidentifying restrictions to confirm the validity of our internal instruments and (ii) a second-order serial correlation test to confirm the absence of autocorrelation. $\frac{11}{}$ Failure to reject the null hypothesis provides support to the model, which is the case in all of our regressions. However, Asiedu and Lien (2011) and Roodman (2007) state that these tests may lose power when the countries-to-instruments ratio, $r=n / i$, is less than 1 . Therefore, we reduce the instrument count by limiting the number of lagged levels to be included as instruments in each regression, so that $r>1$. It may be noted that our main 


\section{Bandyopadhyay, Lahiri, Younas}

results remain robust even when $r<1 . \underline{12}$ Furthermore, following past studies (e.g., Asiedu and Lien, 2011), we use the two-step GMM estimator in all regressions, which is considered asymptotically efficient and robust to all types of heteroskedasticity.

The first differencing of equation (1) in the GMM estimations eliminates the countryspecific fixed effects, which thus takes the following form:

$$
\begin{aligned}
{\left[\ln (\text { aid }, \text { p.c. })_{i t}-\ln (\text { aid, p.c. })_{i, t-1}\right] } & =\alpha_{0}+\alpha_{1}\left[\ln (\text { loans, p.c. })_{i t}-\ln (\text { loans, p.c. })_{i, t-1}\right] \\
& +\alpha_{2}\left[\ln (\text { aid, p.c. })_{i, t-1}-\ln (\text { aid }, \text { p.c. })_{i, t-2}\right] \\
& +\left(X_{i t}^{\prime} \lambda-X_{i, t-1}^{\prime} \lambda\right)+\left(\kappa_{t}-\kappa_{t-1}\right)+\left(\varepsilon_{i t}-\varepsilon_{i, t-1}\right) .
\end{aligned}
$$

\section{ESTIMATION RESULTS}

Tables 2 through 4 present the estimation results. Table 2 presents estimation results when the dependent variable is total aid per capita. The results in column (1) show that the coefficient of log loans per capita is negative and significant at the 1 percent level, suggesting that a higher inflow of foreign loans is associated with a lower aid allocation. As expected, the coefficient of $\log$ GDP per capita is also negative and significant, implying that, all else equal, poorer countries tend to receive more aid. The negatively significant coefficient of log population confirms the size-related bias in aid allocation found in the literature. The variables of log trade openness, log inflation, and its squared term are all statistically significant at the 1 percent level. Both trade openness and inflation have a positive impact on aid, while the negative coefficient of the squared term of log inflation suggests its diminishing effect. As expected, better conditions of political rights and civil liberties positively influence aid, but their effect is not statistically significant.

As a robustness check, we drop the political rights and civil liberties variable and instead include an alternative measure of democracy, "log voice and accountability," which has a positive and significant impact on aid at the 1 percent level (column 2). Similarly, in columns (3) and (4), we replace log GDP per capita with the log infant mortality rate. The positive and significant coefficient of the infant mortality rate confirms that, all else equal, poverty remains a key criterion for aid allocation. The significance of political rights and civil liberties in column (3) and voice and accountability in column (4) further confirms that democratic regimes are given more aid. It may be noted that the $p$-values of both the Hansen- $J$ and second-order autocorrelation tests confirm the validity of the instruments and the absence of serial correlation, respectively.

The inclusion of the new control variables in columns (2) through (4) leaves the coefficient of the loans per capita negative, robust at around -0.037 , and statistically significant at the 1 percent level. This suggests that a 1 percent increase in loans per capita is associated with a -0.037 percent decline in aid per capita. In monetary terms, this amounts to a reduction in total aid per capita of $\$ 2.091$ for the average and $\$ 1.270$ for the median country in our sample. Note that in both columns (2) and (4), the estimated coefficient of lagged log aid per capita is 0.289 , while the estimated coefficient of log loans per capita is -0.037 . Thus, the long-run effect on aid per capita is $0.052(0.037 /(1-0.289))$, which implies that the aid-reduction effect of loans increases over time.

Let us consider an example to gain a better sense of this aid-reduction effect of loans. Take two countries in our study: Mexico, which received the lowest (\$1.12), and Cape Verde, which 


\section{Table 2}

\section{Dependent Variable: Ln (total aid per capita)}

Estimation technique: system-GMM

\begin{tabular}{|c|c|c|c|c|}
\hline & & & & \\
\hline Independent variables & (1) & (2) & (3) & (4) \\
\hline Ln (Offshore bank loans p.c.) & $\begin{array}{l}-0.039^{* * *} \\
(0.000)\end{array}$ & $\begin{array}{c}-0.037^{* * *} \\
(0.000)\end{array}$ & $\begin{array}{c}-0.036^{* * *} \\
(0.000)\end{array}$ & $\begin{array}{c}-0.037^{* * *} \\
(0.000)\end{array}$ \\
\hline Ln (GDP p.c.) & $\begin{array}{l}-0.040^{* * *} \\
(0.000)\end{array}$ & $\begin{array}{l}-0.050 * * * \\
(0.000)\end{array}$ & & \\
\hline Ln (Total aid p.c.), Lg & $\begin{array}{l}0.319 * * * \\
(0.000)\end{array}$ & $\begin{array}{l}0.289 * * * \\
(0.000)\end{array}$ & $\begin{array}{l}0.310^{* * *} \\
(0.000)\end{array}$ & $\begin{array}{l}0.289^{* * * *} \\
(0.000)\end{array}$ \\
\hline Ln (Population) & $\begin{array}{l}-0.050^{* * * *} \\
(0.000)\end{array}$ & $\begin{array}{l}-0.049^{* * * *} \\
(0.000)\end{array}$ & $\begin{array}{l}-0.044^{* * *} \\
(0.000)\end{array}$ & $\begin{array}{l}-0.045^{* * *} \\
(0.000)\end{array}$ \\
\hline Ln (Political rights and civil liberties) & $\begin{array}{c}0.007 \\
(0.402)\end{array}$ & & $\begin{array}{l}0.051^{* * *} \\
(0.000)\end{array}$ & \\
\hline Ln (Trade openness) & $\begin{array}{l}0.073^{* * * *} \\
(0.000)\end{array}$ & $\begin{array}{l}0.095^{* * * *} \\
(0.000)\end{array}$ & $\begin{array}{l}0.009 \\
0.342)\end{array}$ & $\begin{array}{c}0.010 \\
(0.168)\end{array}$ \\
\hline Ln (Inflation) & $\begin{array}{l}0.550^{* * * *} \\
(0.000)\end{array}$ & $\begin{array}{l}0.465^{* * *} \\
(0.000)\end{array}$ & $\begin{array}{l}0.532^{* * * *} \\
(0.000)\end{array}$ & $\begin{array}{l}0.512^{* * * *} \\
(0.000)\end{array}$ \\
\hline Ln (Inflation), Sq & $\begin{array}{l}-0.068^{* * * *} \\
(0.000)\end{array}$ & $\begin{array}{l}-0.056^{* * *} \\
(0.000)\end{array}$ & $\begin{array}{c}-0.061^{* * *} \\
(0.000)\end{array}$ & $\begin{array}{c}-0.056^{* * *} \\
(0.000)\end{array}$ \\
\hline Ln (Voice and accountability) & & $\begin{array}{l}0.107^{* * *} \\
(0.000)\end{array}$ & & $\begin{array}{l}0.152^{* * * *} \\
(0.000)\end{array}$ \\
\hline Ln (Infant mortality rate) & & & $\begin{array}{l}0.023^{* * *} \\
(0.000)\end{array}$ & $\begin{array}{l}0.038^{* * * *} \\
(0.000)\end{array}$ \\
\hline Hansen $J$-test ${ }^{\dagger}$ ( $p$-values) & 0.279 & 0.258 & 0.245 & 0.245 \\
\hline Second-order autocorrelation test ${ }^{\ddagger}$ ( $p$-values) & 0.388 & 0.519 & 0.406 & 0.536 \\
\hline No. of observations & 1,198 & 1,198 & 1,198 & 1,198 \\
\hline No. of countries, $n$ & 114 & 114 & 114 & 114 \\
\hline No. of instruments, $i$ & 113 & 113 & 113 & 113 \\
\hline Instrument ratio, $r=n / i$ & 1.01 & 1.01 & 1.01 & 1.01 \\
\hline Time effects included & Yes & Yes & Yes & Yes \\
\hline
\end{tabular}

received the highest (\$328.43) amount of average aid per capita over the sample period. Then a 1 percent increase in loans per capita will induce a reduction of aid per capita of $\$ 0.042$ in the short run and \$0.056 in the long run for Mexico; the amounts are \$12.152 in the short run and $\$ 16.422$ in the long run for Cape Verde. In overall dollar value, this reduces aid by $\$ 4.217$ million in the short run and \$5.622 million in the long run for Mexico, while for Cape Verde this reduction in aid amounts to $\$ 5.564$ million in the short run and $\$ 7.519$ million in the long run. To offer yet another perspective, the 1 percent increase in loans reduces total aid by $\$ 76.830$ million in the short run and $\$ 103.824$ million in the long run for China, which is the most popu- 


\section{Table 3}

\section{Dependent Variable: Ln (bilateral aid per capita)}

\begin{tabular}{|c|c|c|c|c|}
\hline \multirow[b]{2}{*}{ Independent variables } & \multicolumn{4}{|c|}{ Estimation technique: system-GMM } \\
\hline & (1) & (2) & (3) & (4) \\
\hline Ln (Offshore bank loans p.c.) & $\begin{array}{c}-0.042^{* * *} \\
(0.000)\end{array}$ & $\begin{array}{c}-0.043^{* * *} \\
(0.000)\end{array}$ & $\begin{array}{c}-0.036^{* * *} \\
(0.000)\end{array}$ & $\begin{array}{l}-0.039^{* * *} \\
(0.000)\end{array}$ \\
\hline Ln (GDP p.c.) & $\begin{array}{l}-0.022^{* * *} \\
(0.000)\end{array}$ & $\begin{array}{c}-0.028^{* * *} \\
(0.000)\end{array}$ & & \\
\hline Ln (Bilateral aid p.c.), Lg & $\begin{array}{l}0.242^{* * *} \\
(0.000)\end{array}$ & $\begin{array}{l}0.229^{* * *} \\
(0.000)\end{array}$ & $\begin{array}{l}0.210^{* * *} \\
(0.000)\end{array}$ & $\begin{array}{l}0.176^{* * *} \\
(0.000)\end{array}$ \\
\hline Ln (Population) & $\begin{array}{c}-0.026^{* * *} \\
(0.000)\end{array}$ & $\begin{array}{c}-0.026^{* * *} \\
(0.000)\end{array}$ & $\begin{array}{l}-0.035^{* * *} \\
(0.000)\end{array}$ & $\begin{array}{l}-0.035^{* * *} \\
(0.000)\end{array}$ \\
\hline Ln (Political rights and civil liberties) & $\begin{array}{l}0.040^{* * *} \\
(0.000)\end{array}$ & & $\begin{array}{l}0.015^{* *} \\
(0.033)\end{array}$ & \\
\hline Ln (Trade openness) & $\begin{array}{l}0.048^{* * *} \\
(0.000)\end{array}$ & $\begin{array}{l}0.057^{* * *} \\
(0.000)\end{array}$ & $\begin{array}{l}0.004 \\
0.660)\end{array}$ & $\begin{array}{c}0.004 \\
(0.566)\end{array}$ \\
\hline Ln (Inflation) & $\begin{array}{l}0.487^{* * *} \\
(0.000)\end{array}$ & $\begin{array}{l}0.416^{* * *} \\
(0.000)\end{array}$ & $\begin{array}{l}0.518^{* * *} \\
(0.000)\end{array}$ & $\begin{array}{l}0.503^{* * *} \\
(0.000)\end{array}$ \\
\hline Ln (Inflation), Sq & $\begin{array}{c}-0.061^{* * *} \\
(0.000)\end{array}$ & $\begin{array}{c}-0.051^{* * *} \\
(0.000)\end{array}$ & $\begin{array}{l}-0.061^{* * *} \\
(0.000)\end{array}$ & $\begin{array}{c}-0.058^{* * *} \\
(0.000)\end{array}$ \\
\hline Ln (Voice and accountability) & & $\begin{array}{l}0.025^{* * *} \\
(0.000)\end{array}$ & & $\begin{array}{l}0.066^{* * *} \\
(0.000)\end{array}$ \\
\hline Ln (Infant mortality rate) & & & $\begin{array}{l}0.016^{* * *} \\
(0.000)\end{array}$ & $\begin{array}{l}0.021^{* * *} \\
(0.000)\end{array}$ \\
\hline Hansen $J$-test ${ }^{\dagger}$ ( $p$-values) & 0.241 & 0.365 & 0.266 & 0.240 \\
\hline Second-order autocorrelation test ${ }^{\ddagger}$ ( $p$-values) & 0.375 & 0.385 & 0.428 & 0.541 \\
\hline No. of observations & 1,198 & 1,198 & 1,198 & 1,198 \\
\hline No. of countries, $n$ & 114 & 114 & 114 & 114 \\
\hline No. of instruments, $i$ & 113 & 113 & 113 & 113 \\
\hline Instrument ratio, $r=n / i$ & 1.01 & 1.01 & 1.01 & 1.01 \\
\hline Time effects included & Yes & Yes & Yes & Yes \\
\hline
\end{tabular}

lous country in our sample. For Dominica, the least populous country in our sample, this reduction is $\$ 0.806$ million in the short run and $\$ 1.089$ million in the long run.

Next we examine whether the influence of loans on aid changes when we replace the dependent variable log total aid per capita with log bilateral aid per capita. The results in Table 3 show that log loans per capita has both quantitatively and qualitatively approximately the same effect on log bilateral aid per capita as for log total aid per capita (as in Table 2). The magnitude of the coefficients of log loans per capita ranges from -0.036 (column (3)) to -0.043 (column (2)). In dollar terms, for results in column (2), this amounts to a reduction in bilateral aid per capita 


\section{Table 4}

\section{Excluding OPEC and Transition Economies}

Dependent variables (estimation technique: system-GMM)

\begin{tabular}{|c|c|c|c|c|}
\hline \multirow[b]{3}{*}{ Independent variables } & \multirow{2}{*}{\multicolumn{2}{|c|}{ Excluding OPEC economies }} & & \\
\hline & & & \multicolumn{2}{|c|}{ Excluding OPEC transition economies } \\
\hline & $\begin{array}{c}\operatorname{Ln} \text { (T.A. p.c.) } \\
\text { (1) }\end{array}$ & $\begin{array}{c}\operatorname{Ln} \text { (B.A. p.c.) } \\
\text { (2) }\end{array}$ & $\begin{array}{c}\operatorname{Ln} \text { (T.A. p.c.) } \\
\text { (3) }\end{array}$ & $\begin{array}{c}\operatorname{Ln} \text { (B.A. p.c.) } \\
\text { (4) }\end{array}$ \\
\hline Ln (Offshore bank loans p.c.) & $\begin{array}{c}-0.104^{* * *} \\
(0.000)\end{array}$ & $\begin{array}{l}-0.063^{* * *} \\
(0.002)\end{array}$ & $\begin{array}{l}-0.114^{* * *} \\
(0.000)\end{array}$ & $\begin{array}{l}-0.093^{* * *} \\
(0.000)\end{array}$ \\
\hline Ln (GDP p.c.) & $\begin{array}{c}-0.043^{* * *} \\
(0.000)\end{array}$ & $\begin{array}{c}-0.028^{* * *} \\
(0.000)\end{array}$ & $\begin{array}{l}-0.035^{* * *} \\
(0.000)\end{array}$ & $\begin{array}{l}-0.019 * * * \\
(0.000)\end{array}$ \\
\hline Ln (Total aid p.c.), Lg & $\begin{array}{l}0.105^{* * *} \\
(0.000)\end{array}$ & & $\begin{array}{l}0.109^{* * * *} \\
(0.000)\end{array}$ & \\
\hline Ln (Bilateral aid p.c.), Lg & & $\begin{array}{c}0.007 \\
(0.621)\end{array}$ & & $\begin{array}{c}-0.016 \\
(0.360)\end{array}$ \\
\hline Ln (Population) & $\begin{array}{c}-0.061^{* * *} \\
(0.000)\end{array}$ & $\begin{array}{c}-0.035^{* * *} \\
(0.000)\end{array}$ & $\begin{array}{l}-0.063^{* * *} \\
(0.000)\end{array}$ & $\begin{array}{l}-0.039^{* * *} \\
(0.000)\end{array}$ \\
\hline Ln (Political rights and civil liberties) & $\begin{array}{l}0.084^{* * *} \\
(0.000)\end{array}$ & $\begin{array}{l}0.060^{* * *} \\
(0.000)\end{array}$ & $\begin{array}{l}0.073^{* *} \\
(0.003)\end{array}$ & $\begin{array}{c}0.019 \\
(0.266)\end{array}$ \\
\hline Ln (Trade openness) & $\begin{array}{l}0.169^{* * *} \\
(0.000)\end{array}$ & $\begin{array}{l}0.142^{* * *} \\
(0.000)\end{array}$ & $\begin{array}{l}0.174^{* * * *} \\
0.000)\end{array}$ & $\begin{array}{l}0.170^{* * * *} \\
(0.000)\end{array}$ \\
\hline Ln (Inflation) & $\begin{array}{l}0.936^{* * *} \\
(0.000)\end{array}$ & $\begin{array}{l}0.741^{* * * *} \\
(0.000)\end{array}$ & $\begin{array}{l}1.234^{* * *} \\
(0.000)\end{array}$ & $\begin{array}{l}1.134^{* * *} \\
(0.000)\end{array}$ \\
\hline Ln (Inflation), Sq & $\begin{array}{c}-0.112^{* * *} \\
(0.000)\end{array}$ & $\begin{array}{c}-0.085^{* * *} \\
(0.000)\end{array}$ & $\begin{array}{l}-0.136^{* * *} \\
(0.000)\end{array}$ & $\begin{array}{c}-0.133^{* * *} \\
(0.000)\end{array}$ \\
\hline Hansen $J$-test ${ }^{\dagger}$ ( $p$-values) & 0.435 & 0.765 & 0.385 & 0.472 \\
\hline Second-order autocorrelation test ${ }^{\ddagger}(p$-values) & 0.237 & 0.210 & 0.245 & 0.195 \\
\hline No. of observations & 1,130 & 1,130 & 972 & 972 \\
\hline No. of countries, $n$ & 107 & 107 & 92 & 92 \\
\hline No. of instruments, $i$ & 85 & 85 & 85 & 85 \\
\hline Instrument ratio, $r=n / i$ & 1.26 & 1.26 & 1.08 & 1.08 \\
\hline Time effects included & Yes & Yes & Yes & Yes \\
\hline
\end{tabular}

NOTE: T.A., total aid; B.A., bilateral aid; Sq, squared; Lg, lagged, p.c., per capita. We use a two-step estimation for the system-GMM, which is considered asymptotically efficient and robust to all types of heteroskedasticity. ${ }^{* * *}$ indicates significance at the 1 percent level. $p$-Values are listed in parentheses. ${ }^{+}$The null hypothesis is that the instruments are not correlated with the residuals. ${ }^{\ddagger}$ The null hypothesis is that the error term exhibits no second-order serial correlation.

of $\$ 1.525$ for the average and $\$ 1.476$ for the median country in our sample. This long-run effect is $0.056(0.043 /(1-0.229))$, which further strengthens our finding that the aid-reduction effect of loans increases over time. The sign, significance, and interpretation of all other control variables do not change. $\underline{13}$

Finally, we check whether our results are sensitive to the exclusion of Organization of the Petroleum Exporting Countries (OPEC) and transition economies. $\frac{14}{}$ The reason for excluding OPEC economies is that since they generate high domestic savings and foreign reserves through the sale of oil in domestic and international markets, they do not depend as such on foreign aid 


\section{Bandyopadhyay, Lahiri, Younas}

for funding development projects. In fact, OPEC economies received substantially less aid relative to other countries over the sample period. Transition economies, on the other hand, have received substantially more aid mainly because of the structural changes and other economic and political transformations that took place there starting in the early 1990s. In Table 4, columns (1) and (2) report results when we exclude OPEC economies from our sample, while columns (3) and (4) present results when we exclude both OPEC and transition economies. The signs and significance of all these variables strongly support our findings in Tables 2 and 3. In fact, the negative coefficient of log loans per capita is substantially larger in all the regressions in Table 4 than those in Tables 2 and 3. For example, for regressions when the dependent variable is log total aid per capita, the negative coefficient of log loans per capita is -0.104 when only OPEC economies are excluded, while it is -0.114 when both OPEC and transition economies are excluded. This further confirms that better access to foreign credits significantly reduces the allocation of foreign aid to developing countries.

\section{CONCLUSION}

This article investigates whether more credit-constrained developing countries receive larger amounts of foreign aid. We use alternative econometric techniques to derive estimation results. In particular, we use a dynamic panel generalized method of moments (GMM) estimator, mainly to address the endogeneity problem in multiple variables. We use various controls aside from the main variables of interest and use different definitions of the main variables. All of our regressions strongly support our hypothesis that better access to foreign credit reduces the flow of foreign aid.

\section{NOTES}

1 While reviewing Bauer's (1971) work, Stern (1974) made a robust defense of foreign aid as an instrument for development.

$\underline{2}$ Total aid is the sum of bilateral and multilateral assistance. Since multilateral aid consists primarily of soft loans, we do not focus on it separately and thus limit our analysis to the allocation of total and bilateral aid only. The appendix lists the countries included in our study.

$\underline{3}$ We use this time period for our analysis because of the availability of consistent cross-border lending data by the reporting banks from the BIS.

4 A few alternative data sources for credits are available in the literature. The country-level measures of credit constraints are from the financial development and structure database compiled by Beck, Dermigüç-Kunt, and Levine (2000) and updated by Beck and Demirgüç-Kunt (2009). The sector-level variables such as external finance dependence and asset tangibility are from Rajan and Zingales (1998); these have been updated by Chor and Manova (2012). The BIS data are our third source (see, for example, Papaioannou, 2009, and Hermann and Mihaljek, 2011). The first two sources provide information on the extent of credit constraints and the third source gives us data on the flow of foreign loans. Since the purpose of our article is to compare the flow of net foreign aid with that of net foreign loans received by a country, we use the third source.

$\underline{5}$ Detailed information on the locational banking statistics is available on the BIS website (www.bis.org/statistics/bankstats.htm).

6 All amounts for foreign aid and loans are listed in U.S. dollars.

$\underline{7}$ The World Bank (2010) defines the infant mortality rate as the number of infants who die before reaching 1 year of age per 1,000 live births in a given year. Some data observations for the infant mortality rate are missing for some 
countries. Since these values change slowly over time, we interpolated missing observations by calculating averages from available values (Younas and Bandyopadhyay, 2009, and Younas, 2008).

$\underline{8}$ See the seminal study by Dudley and Montmarquette (1976) for a detailed discussion about the small-country effect on foreign aid allocation.

9 Data on various observations for some variables (including aid and loans) also exhibit negative values. Following others in the literature, we linearly transform all variables by adding a constant in their values so that after log transformation their lowest value equals zero.

10 See Blundell and Bond (1998) for a detailed discussion on the moment conditions and the weight matrix used in the system-GMM estimator.

11 We treat all time-variant explanatory variables as endogenous in our model and our regressions use only internal instruments.

12 See the numbers of instruments used and the $p$-values of both the Hansen J-test and second-order autocorrelation test reported in Tables 2 through 4.

$\underline{13}$ The variable of political rights and civil liberties, which was statistically insignificant in column (1) of Table 2, remains statistically significant for all regressions of log bilateral aid per capita.

14 In our sample, OPEC countries are Algeria, Angola, Ecuador, Iran, Libya, Nigeria, and Venezuela; while transition economies are Albania, Azerbaijan, Cambodia, China, Croatia, Georgia, Kazakhstan, Kyrgyz Republic, Laos, Moldova, Slovenia, Tajikistan, Turkmenistan, Uzbekistan, and Vietnam. In our sample period, most foreign assistance received by OPEC economies was under the "Humanitarian Aid" and "Official Development Assistance (ODA) Loans" categories.

\section{REFERENCES}

Alesina, Alberto and Dollar, David. "Who Gives Foreign Aid to Whom and Why?" Journal of Economic Growth, March 2000, 5(1), pp. 33-63.

Asiedu, Elizabeth and Lien, Donald. "Democracy, Foreign Direct Investment, and Natural Resources." Journal of International Economics, May 2011, 84(1), pp. 99-111.

Arellano, Manuel and Bond, Stephen R. "Some Tests of Specification for Panel Data: Monte Carlo Evidence and an Application to Employment Equations." Review of Economic Studies, April 1991, 58(2), pp. 277-97.

Arellano, Manuel and Bover, Olympia. "Another Look at the Instrumental Variable Estimation of Error Components Models." Journal of Econometrics, July 1995, 68(1), pp. 29-52.

Bauer, Peter T. Dissent on Development: Studies and Debates in Development Economics. London: Widenfeld and Nicolson, 1971.

Beck, Thorsten and Demirgüç-Kunt, Asli. "Financial Institutions and Markets across Countries and over Time: Data and Analysis." Policy Research Working Paper No. 4943, World Bank, May 2009, http://elibrary.worldbank.org/docserver/download/4943.pdf?expires=1350577680\&id=id\&accname=guest\&checksum=248875AFEFF1DF14C9192A70C7D20CAF.

Beck, Thorsten; Demirgüç-Kunt, Aasli and Levine, Ross. "Finance, Inequality and the Poor." Journal of Economic Growth, March 2007, 12(1), pp. 27-49.

Beck, Thorsten; Demirgüç-Kunt, Asli and Levine, Ross. "A New Database on Financial Development and Structure." World Bank Economic Review, 2000, 14(3), pp. 597-605; updated in Beck, Demirgüç-Kunt, and Asli (2009).

Beck, Thorsten; Levine, Ross and Loayza, Norman. "Finance and the Sources of Growth." Journal of Financial Economics, 2000, 58(1-2), pp. 261-300.

Bigsten, Arne; Collier, Paul; Dercon, Stefan; Fafchamps, Marcel; Gauthier, Bernard; Gunning, Jan; Oduro, Abena; Oostendorp, Remco; Patillo, Cathy; Söderbom, Mäns; Teal, Francis and Zeufack, Albert. "Credit Constraints in Manufacturing Enterprises in Africa." Journal of African Economies, March 2003, 12(1), pp. 104-25.

Blundell, Richard and Bond, Stephen. "Initial Conditions and Moment Restrictions in Dynamic Panel Models." Journal of Econometrics, 1998, 87, pp. 115-43. 


\section{Bandyopadhyay, Lahiri, Younas}

Chor, D. and Manova, K. "Off the Cliff and Back? Credit Conditions and International Trade During the Global Financial Crisis." Journal of International Economics, 2012, 87(1), pp. 117-33.

Dudley, Leonard and Montmarquette, Claude. "A Model of the Supply of Bilateral Foreign Aid." American Economic Review, March 1976, 66(1), pp. 132-42.

Freedom House. Freedom in the World 2010: The Annual Survey of Political Rights and Civil Liberties. New York: Freedom House, 2010.

Galindo, Arturo and Schiantarelli, Fabio, eds. Credit Constraints and Investment in Latin America. Washington, DC: Inter-American Development Bank, 2003.

Harrison, Ann and McMillan, Margaret. "Does Direct Foreign Investment Affect Domestic Credit Constraints?" Journal of International Economics, October 2003, 61(1), pp. 73-100.

Hayakawa, K. "Small Sample Bias Properties of the System GMM Estimator in Dynamic Panel Data Models." Economics Letters, 2007, 95(1), pp. 32-38.

Héricourt, Jérôme and Poncet, Sandra. "FDI and Credit Constraints: Firm Level Evidence in China." Universite Paris I Pantheon-Sorbonne-TEAM, February 2007; http://halshs.archives-ouvertes.fr/docs/00/14/46/21/PDF/Bla07009.pdf.

Herrmann, S. and Mihaljek, D. “The Determinants of Cross-Border Bank Flows to Emerging Markets: New Evidence on the Spread of Financial Crises." BOFIT Discussion Paper No. 3/2011, Bank of Finland, March 3, 2011; http://papers.ssrn.com/sol3/papers.cfm?abstract id=1803072.

Kaufmann, Daniel; Kraay, Aart and Mastruzzi, Massimo. “Governance Matters VIII: Governance Indicators 1996-2008." Policy Research Working Paper 4978, June 2009;

https://openknowledge.worldbank.org/bitstream/handle/10986/4170/WPS4978.pdf? sequence=1.

Levine, Ross. "More on Finance and Growth: More Finance, More Growth?" Federal Reserve Bank of St. Louis Review, July/August 2003, 85(4), pp. 141-53; http://research.stlouisfed.org/publications/review/03/07/Levine.pdf.

Loayza, Norman; Olaberría, Eduardo; Rigolini, Jamele and Christiaensen, Luc. “Natural Disasters and Growth: Going Beyond the Averages." World Development, July 2012, 40(7), pp. 1317-35.

Papaioannou, Elias. "What Drives International Financial Flows? Politics, Institutions and Other Determinants." Journal of Development Economics, March 2009, 88(2), pp. 269-81.

Rajan, Raghuram and Zingales, Luigi. "Financial Dependence and Growth." American Economic Review, June 1998, 88(3), pp. 559-86.

Roodman, David. "A Note on the Theme of Too Many Instruments." Working Paper No. 125, Center for Global Development, August 2007, revised May 2008; www.cgdev.org/files/14256 file Instruments.pdf.

Stern, Nicholas H. “Professor Bauer on Development: A Review Article." Journal of Development Economics, 1974, 1, pp. 191-211.

Trumbull, William N. and Wall, Howard J. "Estimating Aid Allocation Criteria with Panel Data." Economic Journal, July 1994, 104(425), pp. 876-82.

World Bank. World Development Indicators, 2010. World Bank, Washington, DC, 2010.

Younas, Javed and Bandyopadhyay, Subhayu. “Do Donors Care About Declining Trade Revenue from Liberalization? An Analysis of Bilateral Aid Allocation." Federal Reserve Bank of St. Louis Review, May/June 2009, 91(3), pp. 141-53; http://research.stlouisfed.org/publications/review/09/05/Younas.pdf.

Younas, Javed. (2008). “Motivation for Bilateral Aid Allocation: Altruism or Trade Benefits.” European Journal of Political Economy, September 2008, 24(3), pp. 661-74. 


\section{APPENDIX}

\section{Countries in This Study}

\begin{tabular}{|c|c|c|}
\hline Albania & Gambia & Nigeria \\
\hline Algeria & Georgia & Oman \\
\hline Angola & Ghana & Pakistan \\
\hline Argentina & Grenada & Panama \\
\hline Azerbaijan & Guatemala & Papua New Guinea \\
\hline Bahrain & Guinea & Paraguay \\
\hline Bangladesh & Guinea-Bissau & Peru \\
\hline Benin & Guyana & Philippines \\
\hline Bhutan & Haiti & Rwanda \\
\hline Bolivia & Honduras & Samoa \\
\hline Botswana & India & Senegal \\
\hline Brazil & Indonesia & Seychelles \\
\hline Burkina Faso & Iran & Sierra Leone \\
\hline Burundi & Jordan & Slovenia \\
\hline Cambodia & Kazakhstan & Solomon Islands \\
\hline Cameroon & Kenya & South Africa \\
\hline Cape Verde & Kyrgyz Republic & Sri Lanka \\
\hline Central African Republic & Laos & St. Lucia \\
\hline Chad & Lebanon & Sudan \\
\hline Chile & Lesotho & Swaziland \\
\hline China & Libya & Syria \\
\hline Colombia & Madagascar & Tajikistan \\
\hline Comoros & Malawi & Tanzania \\
\hline Congo, Democratic Republic of the & Malaysia & Thailand \\
\hline Congo, Republic of the & Maldives & Togo \\
\hline Costa Rica & Mali & Tonga \\
\hline Cote d'Ivoire & Malta & Trinidad and Tobago \\
\hline Croatia & Mauritania & Tunisia \\
\hline Djibouti & Mauritius & Turkey \\
\hline Dominica & Mexico & Turkmenistan \\
\hline Dominican Republic & Moldova & Uganda \\
\hline Ecuador & Mongolia & Uruguay \\
\hline Egypt & Morocco & Uzbekistan \\
\hline El Salvador & Mozambique & Venezuela \\
\hline Eritrea & Namibia & Vietnam \\
\hline Ethiopia & Nepal & Yemen \\
\hline Fiji & Nicaragua & Zambia \\
\hline Gabon & Niger & Zimbabwe \\
\hline
\end{tabular}

NOTE: Oil-producing and exporting countries (OPEC) countries are Algeria, Angola, Ecuador, Iran, Libya, Nigeria, and Venezuela. Transition economies are Albania, Azerbaijan, Cambodia, China, Croatia, Georgia, Kazakhstan, Kyrgyz Republic, Laos, Moldova, Slovenia, Tajikistan, Turkmenistan, Uzbekistan, and Vietnam. 


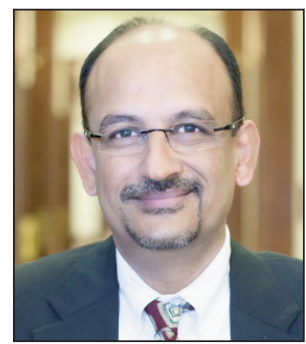

\section{Subhayu Bandyopadhyay}

Research officer and economist, Federal Reserve Bank of St. Louis

http://research.stlouisfed.org/econ/bandyopadhyay/

\section{Research Focus}

Subhayu Bandyopadhyay's research areas are international trade, development economics, and labor economics.

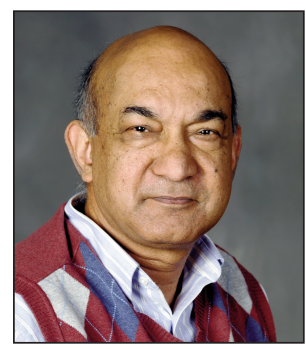

\section{Sajal Lahiri}

Vandeveer Professor of Economics, Southern Illinois University-Carbondale

http://mypage.siu.edu/lahiri

\section{Research Focus}

Sajal Lahiri's areas of interest are foreign direct investment, foreign aid, international trade with environmental externalities, the political economy of trade policy, child labor, and the economics of conflict.

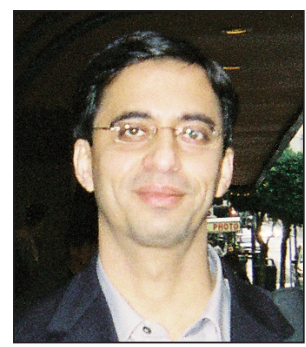

\section{Javed Younas}

Assistant professor of economics, American University of Sharjah, United Arab Emirates

https://www2.aus.edu/facultybios/profile.php?faculty=jyounas

\section{Research Focus}

Javed Younas's research interests are international economics, development economics, conflicts, and terrorism. 